\title{
Dossiê Samuel Beckett: Apresentação
}

\author{
Fábio de Souza Andrade (ORg).
}

Universidade de São Paulo

Experimental por vocação, mas construída em forte diálogo com a tradição literária e filosófica do ocidente, a poética beckettiana convida naturalmente a uma pluralidade imensa de abordagens interpretativas, seja ao instalar-se na confluência entre a criação e a teoria ou no limite entre as artes, seja ao explorar e redefinir a encruzilhada moderna de gêneros e formas dramáticas, narrativas e líricas.

Os artigos que compõem este dossiê, resultado de pesquisas conduzidas no âmbito do Grupo de Pesquisa Estudos sobre Samuel Beckett, da FFLCH-USP, exploram este universo de problemas e provocações a partir de ângulos muito variados, aproximando-o ora da linguística, ora da filosofia, ora da crítica de artes. Assim, o cânone beckettiano deixa-se ler, aqui, tanto a partir de procedimentos específicos (a centralidade da imagem e a assimilação profunda do duplo na narrativa e no drama do autor de Godot), de afinidades eletivas (o parentesco de sua obra final com a teoria estética adorniana e diálogo de sua obra com o projeto estético de Bruce Nauman, entrelaçando palavra, gesto e performance em múltiplos suportes), de construtos teóricos (o conceito semiótico de figuralidade, mais compreensivo e compreensível, a um tempo, a partir do espelhamento na obra do irlandês).

São tentativas de "falhar melhor" diante da imensa complexidade e prazer que o texto beckettiano provoca, provocações elas mesmas, incitando o leitor a multiplicar as respostas que este universo tão intrincado - mas tão próximo da nossa experiência moderna - legitimamente espera. Longe do fim, pedindo um (vários) recomeço(s). 